Vol. 12 (2003): 133-145.

\title{
Effect of conservation tillage and peat application on weed infestation on a clay soil
}

\author{
Petri Vanhala \\ MTT Agrifood Research Finland, Plant Production Research, FIN-31600 Jokioinen, Finland, \\ e-mail: petri.vanhala@mtt.fi \\ Liisa Pietola \\ Department of Applied Chemistry and Microbiology, Agricultural Chemistry and Physics Division, \\ PO Box 27, FIN-00014 University of Helsinki, Finland
}

\begin{abstract}
Amendment of soil with peat is an attempt to avoid crop yield variation in the transition to conservation tillage, as it improves seedbed conditions and crop growth in drought-sensitive clay soils. Weed infestations were compared in 1999-2000 between the original and peat-amended clay (Typic Cryaquept, very fine, illitic or mixed) under different autumn tillage systems in an oats-barley rotation. In a field experiment, sphagnum peat $(\mathrm{H}=4)$ had been spread $\left(0.02 \mathrm{~m}^{3} \mathrm{~m}^{-2}\right)$ on the soil surface in August 1995. Tillage treatments included mouldboard ploughing (to $20 \mathrm{~cm}$ ) and stubble cultivations of different working depths ( 8 or $15 \mathrm{~cm}$ ) and intensity (once or twice). Weed biomass and density were assessed by an area of $1 \mathrm{~m}^{2}$ per field plot in August 1999-2000 and June 2000. The 1999 season was dry, but soil moisture conditions were more favourable in 2000. Peat application tended to increase the number of volunteer oats and Chenopodium album in 1999, while decreasing Galium spurium biomass. Ploughing significantly increased the abundance of Chenopodium album and Lamium purpureum in barley (Hordeum vulgare) in 1999. Weed infestation was much lower in 2000, and tillage effect on Chenopodium album was minor in oats (Avena sativa). Growth of Lamium purpureum and Fumaria officinalis was stimulated in ploughed soils both years. Intensity and working depth of stubble cultivation had no significant effect on weeds.
\end{abstract}

Key words: Avena sativa, Chenopodium album, clay soil, stubble cultivation, Fumaria officinalis, Hordeum vulgare, Lamium purpureum, mouldboard ploughing

\section{Introduction}

Amendment of soil with peat provides an option for farmers to avoid crop yield variation between years and different tillage systems. During the transition to conservation tillage the application of partly decayed organic material such as peat may help to maintain mineral soil productivity (Pietola and Tanni 2003). Even though not com-

(C) Agricultural and Food Science in Finland

Manuscript received April 2003 


\section{Vanhala, P. \& Pietola, L. Effect of tillage and peat on weed infestation}

monly used in arable fields, this new management practice may become more popular in the future, and therefore, data regarding the impact of peat on weeds are needed.

Discontinuation of mouldboard ploughing typically decreases crop yields initially (Pitkänen 1994), especially in dry years (Pietola and Tanni 2003). The main reasons for this decrease are coarse seedbed and poor crop establishment before soil structure improves as a result of increased organic material on the soil surface. Even though the residue cover decreases evaporation and preserves soil moisture in unploughed soils (Gill and Prihar 1983, Steiner 1989), the soil structure needs a transition period to adapt to the new tillage system. Improved soil $\mathrm{C}, \mathrm{N}$ and water retention by peat can promote growth even five years after the application (Pietola and Tanni 2003). Although the soil improvement effect is clear, the low income of grain production prevents farmers from taking advantage of this benefit (Pietola and Tanni 2003).

Environmental factors affected by peat amendment and soil tillage also regulate weed emergence, establishment and growth. Tillage causes soil disturbance and exposes buried seeds to light, thus inducing germination (Hartmann and Nezadal 1990). The majority of weed seedlings emerge from the top layer (often less than $3 \mathrm{~cm}$, depending on the species) of soil (Grundy et al. 1996, Mohler and Galford 1997); however, the more deeply the seeds are buried, the longer their viability is preserved (Mohler and Galford 1997, Omami et al. 1999). Tillage and peat modify such soil growth factors as temperature, water supply, aeration and nutrients, all of which affect weed infestation (Gutterman et al. 1992, Forcella et al. 1997, Chachalis and Reddy 2000). Moreover, temperature and availability of light, water and nutrients affect competition between crop plants and weeds (Patterson 1995, Carson et al. 1999).

Different primary tillage practices have therefore often led to diversification of weed flora. The effects on weed flora vary widely due to differences in local conditions and weed management. In some cases, seeds (Feldman et al.
1997) and weed plants (Skuterud et al. 1996, Boström 1999) have been found to increase in unploughed soils, although contrary findings also exist; Tørresen (1998) reported the highest emergence rates in ploughing, intermediate rates in harrowing and the lowest rates in no-tillage. Reduced tillage seems to favour perennial and monocot weeds (Skuterud et al. 1996). The infestation of couch grass (Elymus repens L.) in reduced tillage, especially in Nordic conditions, is often so severe that chemical control with glyphosate is needed (Pitkänen 1994). Abundant data show that mouldboard ploughing leads to a relatively homogeneous distribution of seeds in the upper $15-25 \mathrm{~cm}$ of soil, while in shallow or no-tillage weed seeds tend to accumulate on or near the soil surface (e.g. Clements et al. 1996).

In addition to tillage, peat application modifies mineral soil properties including soil water content and seedbed structure (Pietola and Tanni 2003). This may also contribute to weed infestation, as soil conditions become more favourable for weed emergence and growth. Little if any information is, however, available on the effect of peat application on weed infestation. Moreover, most tillage studies have included only one working depth and intensity for each cultivator. Vanhala and Pitkänen (1998) indicated that working depth (10-15 cm vs. $20-25 \mathrm{~cm}$ ) might be more important than tillage implement (plough or stubble cultivator) in determining weed infestation. Working depth also affects the distribution of peat amendment - whether peat is ploughed into a larger soil volume or incorporated closer to the soil surface.

The study had two objectives. The role of peat application in weed infestation during adoption of conservation tillage was examined. Also evaluated were the effects of tillage working depth and intensity on weed infestation. Mouldboard ploughing was compared with stubble cultivation systems employing two tillage depths and two intensities of a commonly used cultivator. Typical Nordic conditions with dry early seasons and common tillage practices were examined in a field experiment on drought-sensitive clay soil with an oats-barley crop rotation. We expected 
Vol. 12 (2003): 133-145.

to find increased weed infestations in plots with peat amendments and greater peat-induced infestation in stubble-cultivated soil than in ploughed soil. We also anticipated higher weed infestations in the more intensively than in less intensively tilled soils.

\section{Material and methods}

The experiment was established on clay soil (Typic Cryaquept, very fine, illitic or mixed) (Yli-Halla and Mokma 2001) in Jokioinen $\left(60^{\circ} 49^{\prime} \mathrm{N} ; 2^{\circ} 28^{\prime} \mathrm{E}\right)$ in September 1995. A splitplot design with six replicates was used. The effects of peat application were studied in the main plots, which were divided into subplots $(5 \mathrm{~m} \times 15 \mathrm{~m})$ according to different soil tillage practices. Sphagnum peat (von Post's $\mathrm{H}=4, \mathrm{C}=$ $45 \%)$ was spread $\left(0.02 \mathrm{~m}^{3} \mathrm{~m}^{-2}\right)$ on the soil surface of 50\% of the main plots in August 1995, before autumn tillage. Since 1995, the field had been tilled each September with a $2 \times 14$ " mouldboard plough (MP) to a depth of $20 \mathrm{~cm}$, or with a stubble cultivator (SC) ("Kverneland Turbo 2") to a depth of 8 or $15 \mathrm{~cm}$, once or twice. In May, the seedbed was tilled using a rotary harrow to a sowing depth of $6 \mathrm{~cm}$. Because of very dry conditions at spring tillage and sowing, the soil surface was also levelled before seedbed preparations to reduce evaporation.

A combined seed and fertilizer drill ( $\mathrm{N} 90$ $\mathrm{kg} \mathrm{ha}^{-1}$ ) with seed row spacing of $125 \mathrm{~mm}$ was used for sowing of spring cereals: Oats (Avena sativa L.) was sown in 1996, barley (Hordeum vulgare L.) in 1997 and oats in 1998. In the last two years, barley was sown on 12 May 1999 and oats on 6 May 2000. In 1996 and 1998, oat stands were sprayed with MCPA + Mecoprop-P 540/ $610 \mathrm{~g}$ a.i. ha $^{-1}$. No herbicides were used in 1997 and 1999-2000 because of a drought at the most convenient spraying time.

This study focuses on the years 1999 and 2000 , i.e. 4-5 years after discontinuation of mouldboard ploughing in conservation tillage systems. Crop yield as well as weed biomass and density were assessed. Grain yield was harvested on 17 August 1999 and 30 August 2000 on $2.1 \mathrm{~m} \times 10 \mathrm{~m}$ areas per subplot, for each treatment on the same day. Grain moisture was determined gravimetrically from a subsample (40 g). Weeds were counted on 17-18 August 1999, 21 June 2000 and 9-10 August 2000. The sample area was $1 \mathrm{~m}^{2}$ per plot, consisting of four $0.5 \mathrm{~m} \times 0.5 \mathrm{~m}$ quadrats (August 1999, June 2000) or two $1 \mathrm{~m} \times 0.5 \mathrm{~m}$ quadrats (August 2000). In June 2000, the weeds were counted in a non-destructive manner, without removing them. In August 1999 and 2000, weeds in the sample areas were removed, and in addition to counting, their air-dry biomass was weighed. The dominant species and the sum of the other species were subjected to statistical analyses. The nomenclature of weed species follows that of Bayer (1992).

Weather conditions for 1999 and 2000 in Jokioinen are given in Table 1 . The 1999 season was dry because of low rainfall before July 20 . Night frosts and winds in the early season also contributed to the dry soil condition. The barley stand remained short. In the rainier year of 2000 , the oats stand developed to a height of 90 $110 \mathrm{~cm}$.

Statistical analyses were performed as described by Steel and Torrie (1981) and Ranta et al. (1991). Analyses of variance (ANOVA) of soil and plant parameters were evaluated according to the split-plot design with six replicates, where two peat application schemes represented the main treatments. Group of means were compared using Tukey's Honestly Significant Difference test to find statistically significant $(\mathrm{P}<0.05)$ differences.

\section{Results}

Peat application had no significant effect on weed communities (Tables 2 and 3, Figs 1-4). In 1999, the density of Chenopodium album L. 
Vanhala, P. \& Pietola, L. Effect of tillage and peat on weed infestation

Table 1. Weather conditions in Jokioinen in 1999-2000 and the 30-year average. Data provided by the Finnish Meteorological Institute. Sowing dates were 8 May 1999 and 16 May 2000. Harvesting dates were 17 August 1999 and 30 August 2000.

\begin{tabular}{lccccccc}
\hline & \multicolumn{3}{c}{ Mean air temperature, ${ }^{\circ} \mathrm{C}$} & \multicolumn{3}{c}{ Precipitation, mm } \\
& 1999 & 2000 & $1960-90$ & 1999 & 2000 & $1960-90$ \\
\hline May & 7.5 & 10.3 & 9.4 & 13 & 27 & 35 \\
June & 17.4 & 13.4 & 14.3 & 30 & 49 & 47 \\
July & 17.5 & 15.6 & 15.8 & & 49 & 112 & 80 \\
August & 14.1 & 14.1 & 14.2 & & 55 & 84 & 83 \\
Mean & 14.1 & 13.4 & 13.4 & Total & 147 & 272 & 245 \\
\hline
\end{tabular}

was higher in treatments with peat than without peat within each tillage treatment, but the difference was not statistically significant (Table 3, Fig. 1). The dry mass of volunteer oats Avena sativa $\mathrm{L}$. tended to be higher in 1999 in peatamended soils than without peat application. In contrast, peat application tended to decrease the dry mass of Lamium purpureum L. $(\mathrm{P}=0.11)$ and Galium spurium L. (Table 2).

Tillage treatments had significant effects on weed infestations. In 1999, mouldboard ploughing crucially increased the abundance of $C$. album (Tables 2 and 3, Fig. 1). In the ploughed soils, the density of $C$. album was on average 44 plants $\mathrm{m}^{-2}$, whereas 7 plants $\mathrm{m}^{-2}$ were found in stubble-cultivated soils (Fig. 1). No significant effects of intensity or depth of stubble cultivation were, however, observed (Table 3). Lamium purpureum was also much more abundant in the ploughed soils than in stubble-cultivated soils (Tables 2 and 3, Fig. 1). Furthermore, dry masses of Fumaria officinalis L. were higher in ploughed soils than in stubble cultivation (Table 2). Stellaria media (L.) Vill./Cyr. plants profited from ploughing or two deep stubble cultivations (Table 2). Galium spurium plants also tended to increase with the most intensive tillage. Biomass of all "other weed species" (see Table 4) was clearly higher in ploughed soils than in other tillage treatments, especially those without peat application (Table 2). Stubble cultivation decreased the growth of these weeds, but increased the density of volunteer oats (A. sati$v a$ ) compared with ploughed soil (Tables 2 and 3, Fig. 4).

In 2000, L. purpureum was stimulated by mouldboard ploughing (Tables 2 and 3, Fig. 1). Fumaria officinalis was also more abundant in ploughed soils in August 2000 (Tables 2 and 3, Fig. 2). The most intensively tilled soils (mouldboard ploughed or stubble cultivated twice to a depth of $15 \mathrm{~cm}$ ) had more "other" weeds (Table 3, Fig. 3).

Some variation was present in species richness. In each treatment, 16-21 weed species were found (Table 4). The number of species was slightly higher in plots where peat was applied. Peat application particularly seemed to favour Polygonum L. species and Bistorta vivipara (L.) Gray. The number of species was usually slightly higher in treatments with two stubble cultivations than in treatments with only one stubble cultivation or ploughing.

Peat increased crop growth $(\mathrm{P}<0.1$ in 1999 , $\mathrm{P}<0.001$ in 2000) without significant interactions between peat and tillage treatments (Table 5).

Tillage significantly affected crop yields and grain moisture, particularly in the dry 1999 season (Tables 1 and 5). The highest yield was achieved in stubble-cultivated treatments (Table 5). In 2000, when rainfalls occurred in July after a dry early season, tillage practices did not significantly affect crop yields, although grain 
Vol. 12 (2003): 133-145.

Table 2. Effect of peat application $(H=4$, September 1995) and tillage on weed biomass in August 1999 and 2000.

\begin{tabular}{|c|c|c|c|c|c|c|c|c|c|c|}
\hline \multirow[b]{3}{*}{ Treatment } & \multicolumn{10}{|c|}{ Dry mass, $\mathrm{g} \mathrm{m}^{-1}$} \\
\hline & \multicolumn{7}{|c|}{1999} & \multicolumn{3}{|c|}{2000} \\
\hline & $\mathrm{CH}$ & LA & GA & $\mathrm{FU}$ & ST & AV & OT & $\mathrm{CH}^{2}$ & LA & FU \\
\hline \multicolumn{11}{|c|}{ No peat applied: } \\
\hline MP & 29.30 & 6.67 & 0.102 & 0.57 & 0.56 & 0 & 2.06 & 0.35 & 2.80 & 0.73 \\
\hline $\mathrm{SC}_{1}$ & 1.54 & 1.25 & 0.043 & 0.44 & 0.04 & 0.88 & 0.28 & 0.25 & 1.68 & 0.10 \\
\hline $\mathrm{SC}_{2}$ & 3.83 & 1.70 & 0.063 & 0.05 & 0.07 & 0.47 & 0.09 & 0.43 & 1.53 & 0.78 \\
\hline $\mathrm{DC}_{1}$ & 1.97 & 1.22 & 0.037 & 0.07 & 0.03 & 0.69 & 0.02 & 0.08 & 2.07 & 0.18 \\
\hline $\mathrm{DC}_{2}$ & 1.27 & 1.39 & 0.080 & 0.18 & 0 & 0.76 & 0.12 & 0.85 & 1.68 & 0.67 \\
\hline \multicolumn{11}{|l|}{ Peat applied: } \\
\hline MP & 37.30 & 4.98 & 0.083 & 0.44 & 0.27 & 0.03 & 0.61 & 0.28 & 2.47 & 0.43 \\
\hline $\mathrm{SC}_{1}$ & 2.25 & 0.75 & 0.020 & 0.04 & 0.04 & 1.48 & 0.38 & 0.25 & 1.18 & 0.05 \\
\hline $\mathrm{SC}_{2}$ & 3.25 & 1.25 & 0.022 & 0.02 & 0.03 & 2.17 & 0.06 & 0.27 & 1.52 & 0.07 \\
\hline $\mathrm{DC}_{1}$ & 2.02 & 1.21 & 0.017 & 0.10 & 0.06 & 0.90 & 0.22 & 0.53 & 1.62 & 0.32 \\
\hline $\mathrm{DC}_{2}$ & 2.14 & 1.27 & 0.040 & 0.11 & 0.25 & 1.87 & 0.40 & 0.28 & 1.72 & 0.28 \\
\hline \multicolumn{11}{|l|}{ Peat means: } \\
\hline P- & 7.59 & 2.45 & 0.065 & 0.26 & 0.14 & 0.56 & 0.51 & 0.39 & 1.95 & 0.49 \\
\hline $\mathrm{P}+$ & 9.40 & 1.89 & 0.036 & 0.14 & 0.13 & 1.29 & 0.33 & 0.32 & 1.70 & 0.23 \\
\hline $\mathrm{HSD}_{0.05}$ & $\mathrm{NS}^{1}$ & NS & NS & NS & NS & NS & NS & NS & NS & NS \\
\hline \multicolumn{11}{|c|}{ Tillage means: } \\
\hline MP & 33.30 & 5.82 & 0.093 & 0.50 & 0.41 & 0.01 & 1.34 & 0.32 & 2.63 & 0.58 \\
\hline $\mathrm{SC}_{1}$ & 1.90 & 1.00 & 0.032 & 0.24 & 0.04 & 1.18 & 0.33 & 0.25 & 1.43 & 0.08 \\
\hline $\mathrm{SC}_{2}$ & 3.54 & 1.48 & 0.043 & 0.03 & 0.05 & 1.32 & 0.08 & 0.35 & 1.52 & 0.42 \\
\hline $\mathrm{DC}_{1}$ & 2.00 & 1.22 & 0.027 & 0.08 & 0.04 & 0.80 & 0.12 & 0.31 & 1.84 & 0.25 \\
\hline $\mathrm{DC}_{2}$ & 1.71 & 1.33 & 0.060 & 0.15 & 0.12 & 1.32 & 0.26 & 0.57 & 1.70 & 0.48 \\
\hline $\mathrm{HSD}_{0.05}$ & 12.00 & 1.26 & 0.059 & 0.40 & 0.22 & 1.16 & 1.25 & NS & 0.61 & 0.46 \\
\hline
\end{tabular}

$1 \quad$ NS $=$ not significant at $\mathrm{P}<0.05$

2 PEAT $\times$ TILLAGE interaction significant at $\mathrm{P}<0.05$

HSD = Tukey's Honestly Significant Difference

$\mathrm{MP}=$ mouldboard ploughing to $20 \mathrm{~cm}, \mathrm{SC}_{1}=$ one shallow stubble cultivation to $8 \mathrm{~cm}, \mathrm{SC}_{2}=$ two shallow stubble cultivations to $8 \mathrm{~cm}, \mathrm{DC}_{1}=$ one deep stubble cultivation to $15 \mathrm{~cm}, \mathrm{DC}_{2}=$ two deep stubble cultivations to $15 \mathrm{~cm}$. $\mathrm{P}-=$ soil without peat application, $\mathrm{P}+=$ peat amended soil. Weed species with significant effects are presented: $\mathrm{CH}=\mathrm{Chenopo-}$ dium album, $\mathrm{LA}=$ Lamium purpureum, $\mathrm{GA}=$ Galium spurium, $\mathrm{FU}=$ Fumaria officinalis, $\mathrm{ST}=$ Stellaria media, $\mathrm{AV}=$ volunteer Avena sativa.

moisture at harvest was affected (Table 5). In both years, the crops of the most intensively tilled soils, i.e. mouldboard ploughing and stubble cultivation twice to a soil depth of $15 \mathrm{~cm}$, had higher mean grain moisture at harvest than did soils under reduced tillage (Table 5). Thus, intensive soil tillage delayed crop growth, and the reduced competition between crops and weeds likely contributed to increased weed infestation.
Weather had an impact on weed and crop performance. The effect of tillage on weed communities was shown clearly in the dry year of 1999, when crop growth in ploughed soils with lack of rains before July 20, was very weak. Weed growth was more abundant this year than during the moister season of 2000 (Tables 2 and 3 ). In 2000 , drought occurred only at the beginning of the season, and the effect of tillage on 
Vanhala, P. \& Pietola, L. Effect of tillage and peat on weed infestation

Table 3. Group means of peat application (P) and tillage (MP-DC ${ }_{2}$ ) for measurements of plant density in 1999 and 2000. Plant species with significant $(\mathrm{P}<0.05)$ differences are presented. Complete data presented in Figs 1-3.

\begin{tabular}{|c|c|c|c|c|c|c|c|}
\hline \multirow[b]{2}{*}{ Treatment } & \multicolumn{3}{|c|}{ August 1999} & \multirow{2}{*}{$\begin{array}{l}\text { Density, plants } \mathrm{m}^{-1} \\
\text { June } 2000 \\
\text { GA }^{2}\end{array}$} & \multicolumn{3}{|c|}{ August 2000} \\
\hline & $\mathrm{CH}$ & LA & $\mathrm{AV}$ & & LA & $\mathrm{FU}$ & OT \\
\hline \multicolumn{8}{|l|}{ Peat means } \\
\hline P- & 8.5 & 33.4 & 1.40 & 14.5 & 57.4 & 2.50 & 9.77 \\
\hline $\mathrm{P}+$ & 18.9 & 36.2 & 2.57 & 13.5 & 49.5 & 2.17 & 5.10 \\
\hline $\mathrm{HSD}_{0.05}$ & $\mathrm{NS}^{1}$ & NS & NS & NS & NS & NS & NS \\
\hline \multicolumn{8}{|c|}{ Tillage means } \\
\hline MP & 43.5 & 56.5 & 0.08 & 12.8 & 78.8 & 3.67 & 9.42 \\
\hline $\mathrm{SC}_{1}$ & 6.9 & 28.3 & 2.58 & 12.3 & 40.0 & 1.42 & 6.33 \\
\hline $\mathrm{SC}_{2}$ & 6.4 & 30.8 & 2.17 & 15.3 & 43.0 & 1.92 & 4.75 \\
\hline $\mathrm{DC}_{1}^{2}$ & 6.4 & 31.5 & 2.33 & 17.8 & 54.0 & 2.17 & 7.33 \\
\hline $\mathrm{DC}_{2}$ & 5.1 & 26.9 & 2.75 & 11.8 & 51.5 & 2.50 & 9.33 \\
\hline $\mathrm{HSD}_{0.05}$ & 30.4 & 21.3 & 2.62 & NS & 22.8 & 2.10 & 4.65 \\
\hline \multirow{3}{*}{\multicolumn{8}{|c|}{$\begin{array}{l}1 \text { NS }=\text { not significant at } \mathrm{P}<0.05 \\
2 \text { PEAT } \times \text { TILLAGE interaction significant at } \mathrm{P}<0.05 \\
\text { HSD }=\text { Tukey's Honestly Significant Difference }\end{array}$}} \\
\hline & & & & & & & \\
\hline & & & & & & & \\
\hline \multicolumn{8}{|c|}{$\begin{array}{l}\mathrm{MP}=\text { mouldboard ploughing to } 20 \mathrm{~cm}, \mathrm{SC}_{1}=\text { one shallow stubble cultivation to } 8 \mathrm{~cm}, \mathrm{SC}_{2}=\text { two shallow stubble cultiva- } \\
\text { tions to } 8 \mathrm{~cm}, \mathrm{DC}_{1}=\text { one deep stubble cultivation to } 15 \mathrm{~cm}, \mathrm{DC}_{2}=\text { two deep stubble cultivations to } 15 \mathrm{~cm} . \mathrm{P}-=\text { soil } \\
\text { without peat application, } \mathrm{P}+=\text { peat amended soil. } \mathrm{CH}=\text { Chenopodium album, } \mathrm{LA}=\text { Lamium purpureum, } \mathrm{GA}=\text { Galium } \\
\text { spurium, } \mathrm{FU}=\text { Fumaria officinalis, } \mathrm{AV}=\text { volunteer Avena sativa, } \mathrm{OT}=\text { other weeds. }\end{array}$} \\
\hline
\end{tabular}

weed communities was much less pronounced than in 1999. Overall, weed prevalence in 2000 was lower than in 1999. This appears to be due to the strong competition by oats, which grew well in all tillage treatments (Table 5).

\section{Discussion}

The moister conditions achieved by peat application, shown earlier by Pietola and Tanni (2003), did not notably increase weed infestations, which was contrary to expectations. A weak response was, however, shown: volunteer Avena sativa and Chenopodium album profited marginally from peat application in 1999. The advantageous soil conditions for weeds may be cancelled out by increased crop competition (c.f. higher crop yields when peat applied). This hypothesis is supported by Erviö (1972a), who found nitrogen fertilization to reduce weed mass at cereal seed rates of $200 \mathrm{~kg} \mathrm{ha}^{-1}$ or higher due to increased crop competition. The weed density in our experiment, $36-137$ plants $\mathrm{m}^{-2}$, was less than national average, which is 420 plants $\mathrm{m}^{-2}$ in spring cereals in unsprayed conventional fields (Salonen et al. 2001).

Weed infestations were higher in the more intensively tilled soils, as expected. Our finding that $C$. album was favoured by mouldboard ploughing is in agreement with previous studies. Higher C. album biomass (Teasdale et al. 1991), density (Teasdale et al. 1991, Swanton et al. 1999) and seedbanks (Clements et al. 1996) have been found in ploughing than in reduced or no-tillage treatments. Clements et al. (1996) and Mulugeta and Stoltenberg (1997a) also described greater annual variation in C. album in mould- 
Vol. 12 (2003): 133-145.
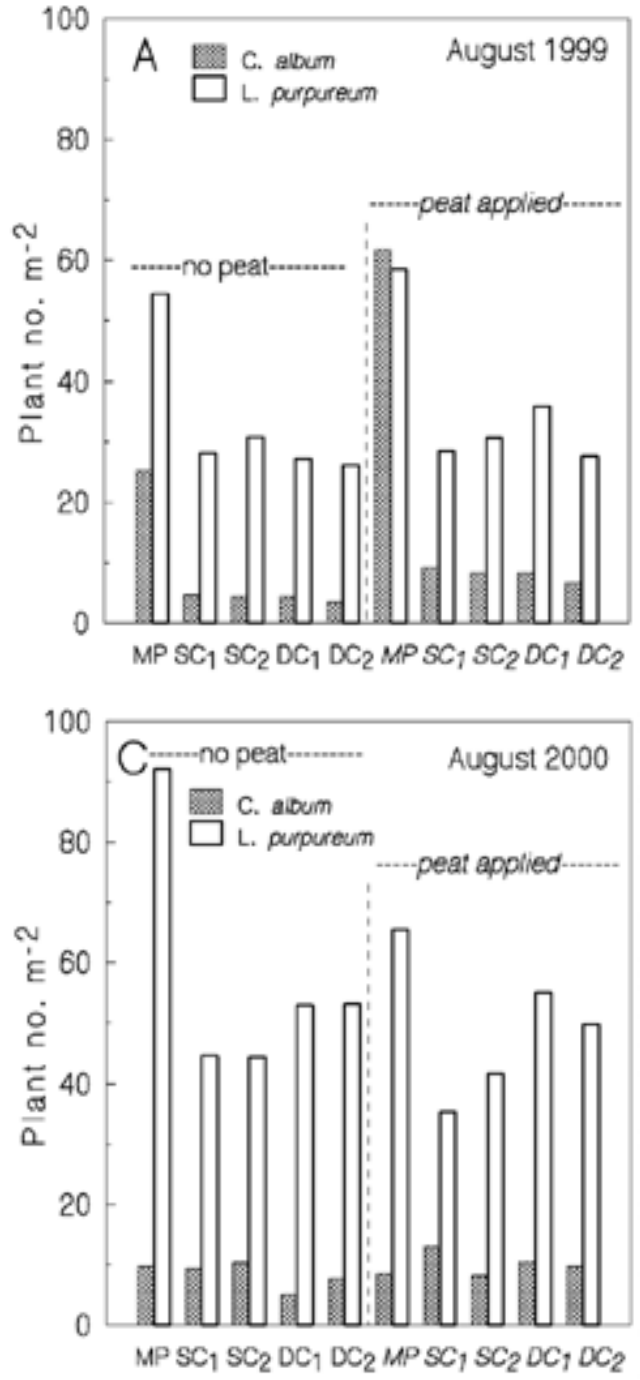

board plough treatments than in some other tillage methods. In our study, C. album was increased in mouldboard ploughed plots in the particularly dry year of 1999. Established C. album plants are also known to tolerate drought (Erviö 1972b).

The majority, up to $79 \%$ (Mulugeta and Stoltenberg 1997b), of C. album seeds are dormant. Because of dormancy, the emerged proportion of C. album is low, e.g. 3\% (Forcella et al. 1997). Seeds that have been buried by ploughing may be more liable to germinate when moved

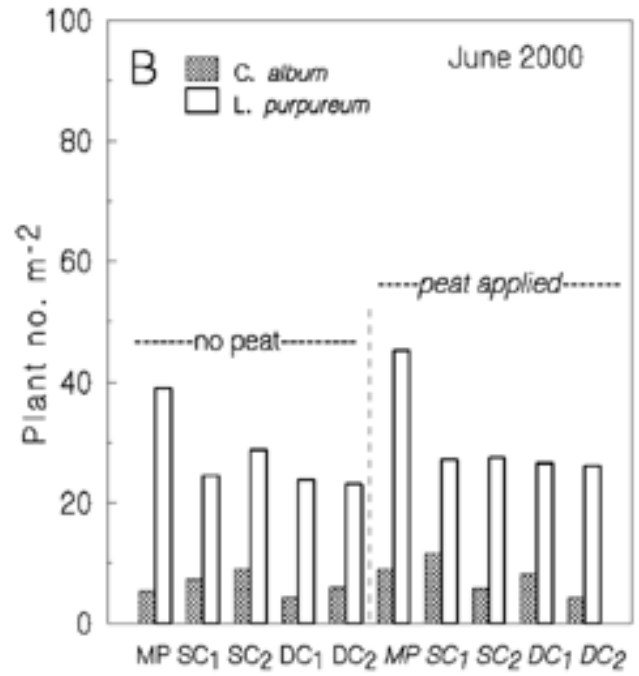

Fig. 1. Density of Chenopodium album and Lamium purpureum in barley crop in August 1999 (A), and in oats in June 2000 (B) and August 2000 (C). MP = mouldboard ploughing (to $20 \mathrm{~cm}$ soil depth); $\mathrm{SC}_{1}=$ shallow $(8 \mathrm{~cm})$ cultivation, once; $\mathrm{SC}_{2}=$ shallow cultivation, twice; $\mathrm{DC}_{1}=$ deep $(15 \mathrm{~cm})$ cultivation, once; $\mathrm{DC}_{2}=$ deep cultivation, twice. $(\mathrm{n}$ =6). Group means and Honestly Significant Differences $\left(\mathrm{HSD}_{0.05}\right)$ when significant $(\mathrm{P}<0.05)$ are presented in Table 3.

nearer to the soil surface (Omami et al. 1999); Mohler and Galford (1997) reported greater emergence of C. album in tilled soil than in untilled soil, and higher seed survival deeper in the soil. In addition, higher emergence and number of $C$. album seedlings in ploughing than in nonploughing appear in response to different soil temperatures and moisture conditions. Finally, soil moisture conditions during the dry summer of 1999 may also have favoured C. album more than barley in ploughed soil as compared with stubble cultivation. 
Vanhala, P. \& Pietola, L. Effect of tillage and peat on weed infestation
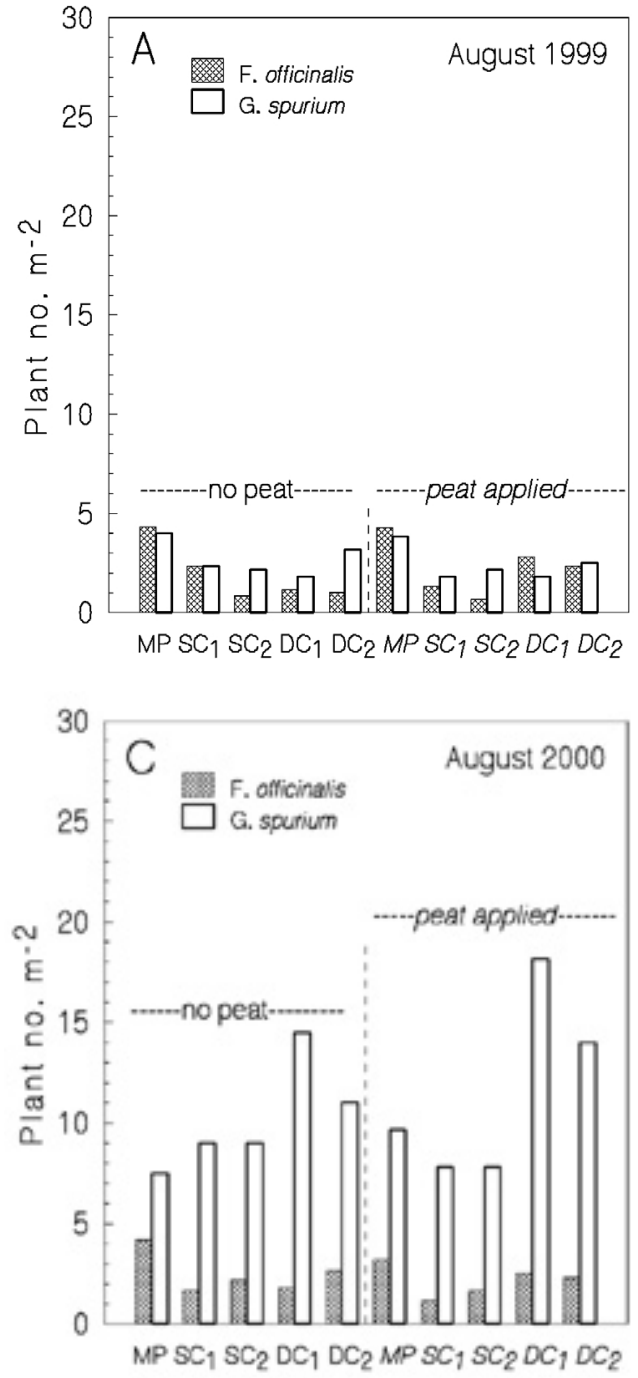

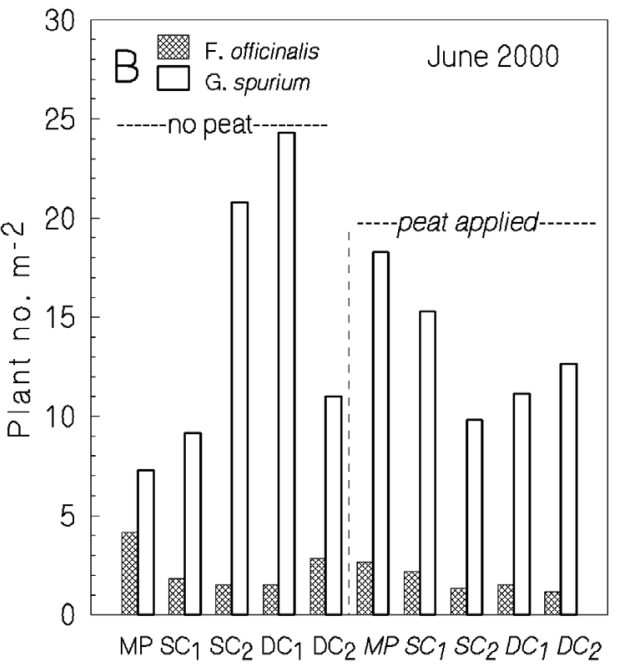

Fig. 2. Density of Fumarium officinalis and Galium spurium in barley crop in August 1999 (A), and in oats in June 2000 (B) and August 2000 (C). MP = mouldboard ploughing (to $20 \mathrm{~cm}$ soil depth); $\mathrm{SC}_{1}=$ shallow $(8 \mathrm{~cm})$ cultivation, once; $\mathrm{SC}_{2}=$ shallow cultivation, twice; $\mathrm{DC}_{1}=\operatorname{deep}(15 \mathrm{~cm})$ cultivation, once; $\mathrm{DC}_{2}=$ deep cultivation, twice. $(\mathrm{n}=6)$. Group means and Honestly Significant Differences $\left(\mathrm{HSD}_{0.05}\right)$ when significant $(\mathrm{P}<0.05)$ are presented in Table 3 .

er Galium spurium plants were present in ploughed plots, although Lee et al. (1994) did find that increased burial duration caused an increase in germination percentage of this species.

Both intensity and working depth of stubble cultivation failed to have a significant effect on weed growth. This finding disagrees with that of Vanhala and Pitkänen (1998), who suggested that working depth is more important than tillage implement. The contradictory finding may 


\section{AGRICULTURAL AND FOOD SCIENCE IN FINLAND}

Vol. 12 (2003): 133-145.
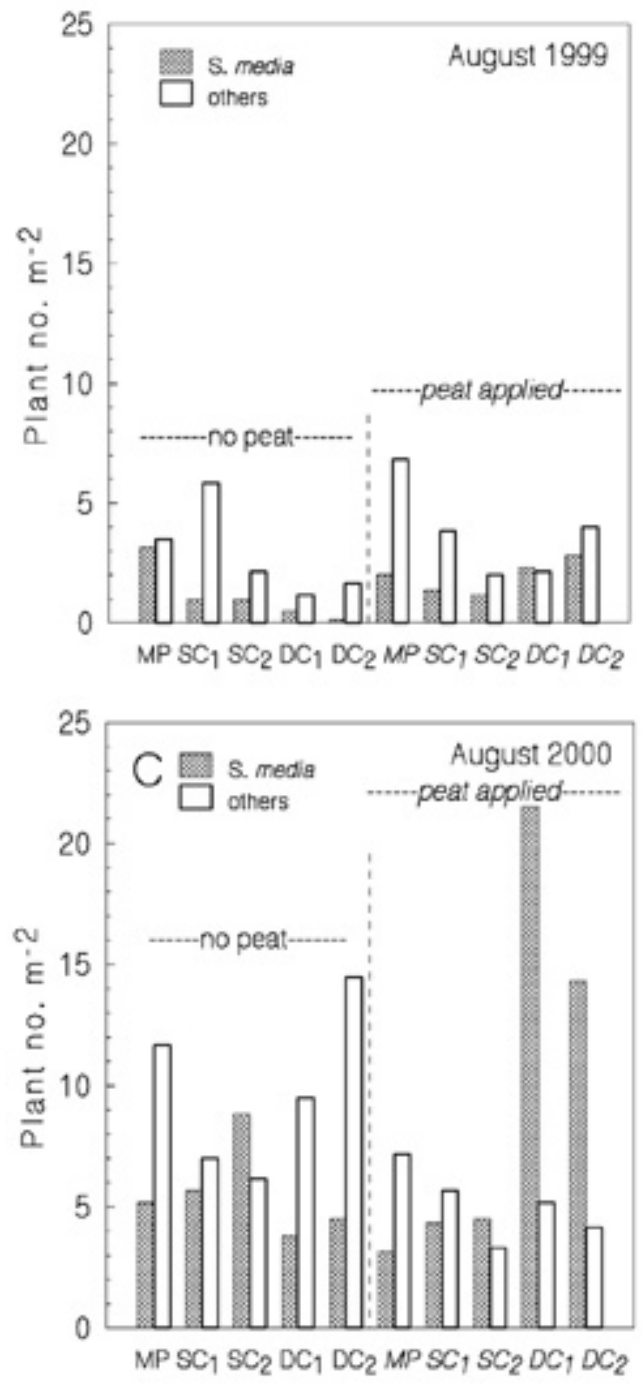

Fig. 4. Density of the previous crop, Avena sativa, in barley crop in August 1999. $\mathrm{MP}=$ mouldboard plouhing (to $20 \mathrm{~cm}$ soil depth); $\mathrm{SC}_{1}=$ shallow $(8 \mathrm{~cm})$ cultivation, once; $\mathrm{SC}_{2}=$ shallow cultivation, twice; $\mathrm{DC}_{1}=\operatorname{deep}(15 \mathrm{~cm})$ cultivation, once; $\mathrm{DC}_{2}=$ deep cultivation, twice. $(\mathrm{n}=6)$. Group means and Honestly Significant Differences $\left(\mathrm{HSD}_{0.05}\right.$ ) when significant $(\mathrm{P}<0.05)$ are presented in Table 3.

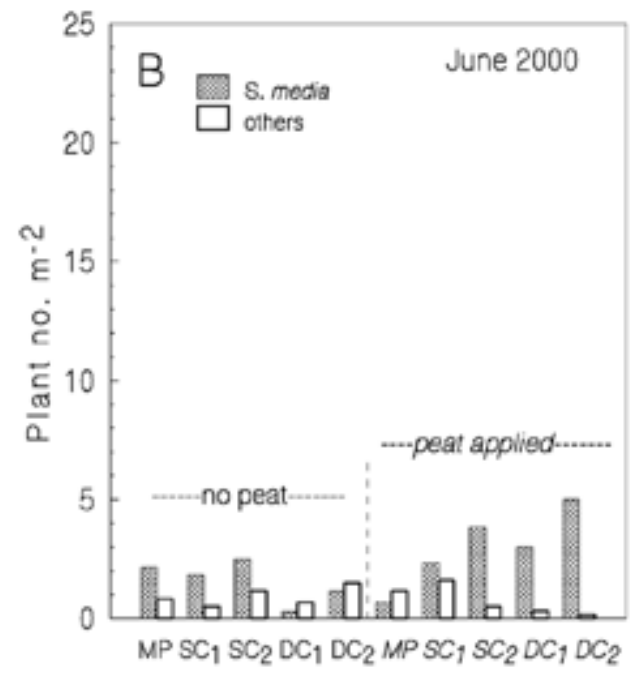

Fig. 3. Density of Stellaria media and other weeds (not included in Figures 2-3) in barley crop in August 1999 (A), and in oats in June 2000 (B) and August 2000 (C). MP = mouldboard ploughing (to $20 \mathrm{~cm}$ soil depth); $\mathrm{SC}_{1}=$ shallow $(8 \mathrm{~cm})$ cultivation, once; $\mathrm{SC}_{2}=$ shallow cultivation, twice; $\mathrm{DC}_{1}=$ deep $(15 \mathrm{~cm})$ cultivation, once; $\mathrm{DC}_{2}=$ deep cultivation, twice. $(n=6)$. Group means and Honestly Significant Differences $\left(\mathrm{HSD}_{0.05}\right)$ when significant $(\mathrm{P}<0.05)$ are presented in Table 3.

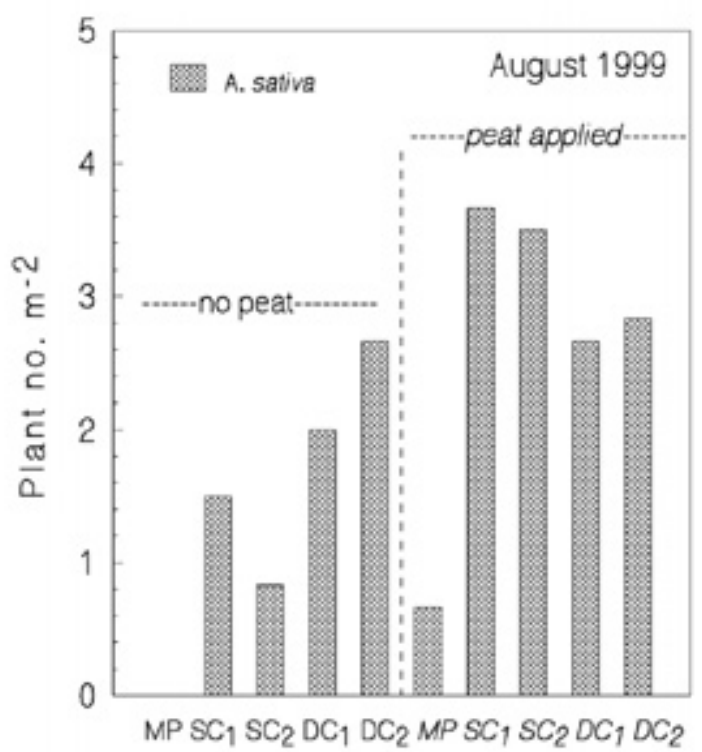


Vanhala, P. \& Pietola, L. Effect of tillage and peat on weed infestation

Table 4. Weed species found in different treatments. $X=$ at least one plant individual of the species found at any of the three assessment times, $-=$ the species was absent in all assessments.

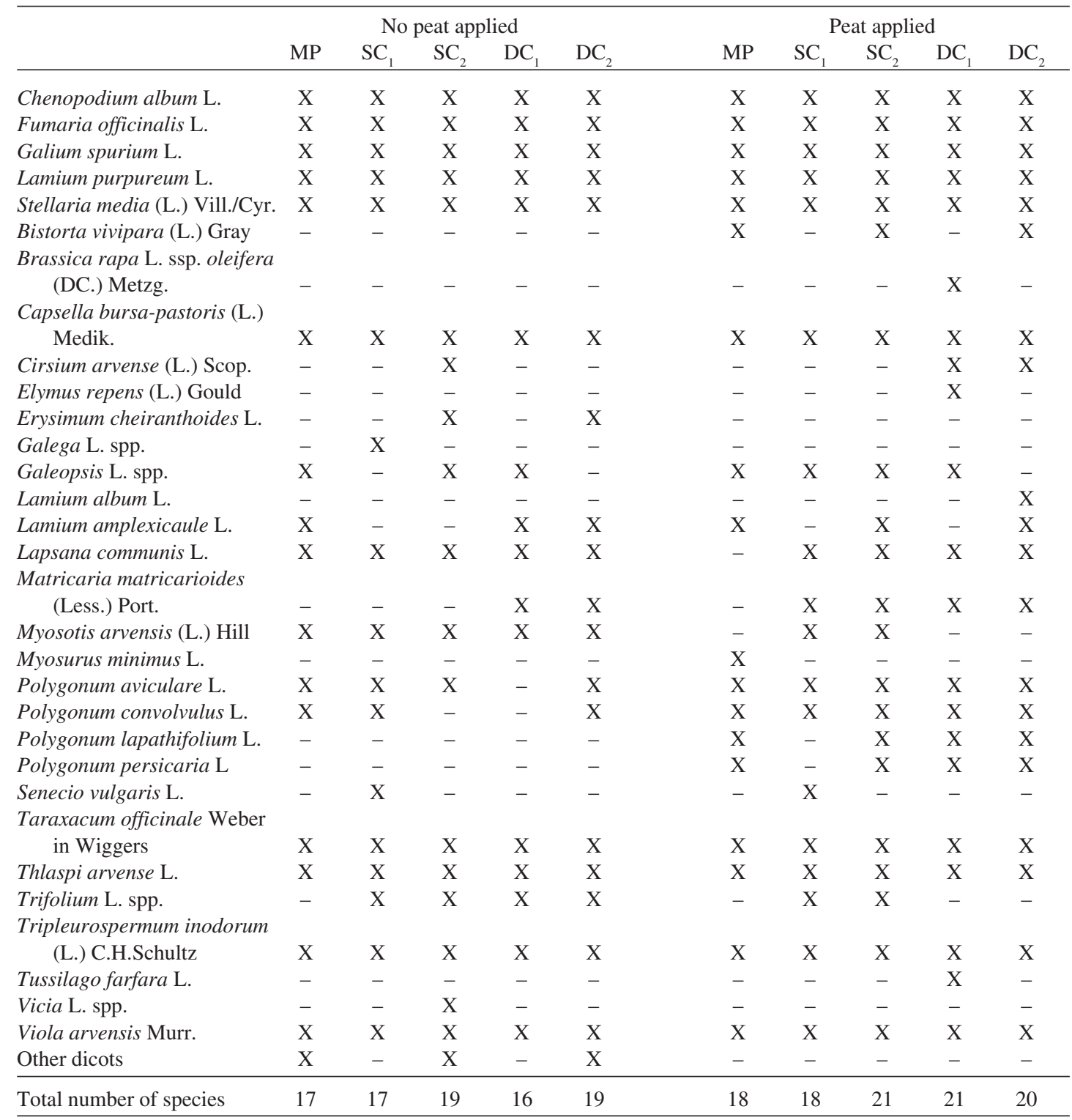

$\mathrm{MP}=$ mouldboard ploughing to $20 \mathrm{~cm}, \mathrm{SC}_{1}=$ one shallow stubble cultivation to $8 \mathrm{~cm}, \mathrm{SC}_{2}=$ two shallow stubble cultivations to $8 \mathrm{~cm}, \mathrm{DC}_{1}=$ one deep stubble cultivation to $15 \mathrm{~cm}, \mathrm{DC}_{2}=$ two deep stubble cultivations to $15 \mathrm{~cm}$. $(\mathrm{n}=6)$

be explained by different working depths. In Vanhala and Pitkänen (1998), the working depths studied were $10-15 \mathrm{~cm}$ and $20-25 \mathrm{~cm}$, whereas our working depths were $8 \mathrm{~cm}$ and $15 \mathrm{~cm}$. The differences in effects of shallow tillage depths on weeds and weed seeds seem to be less extreme. 
Vol. 12 (2003): 133-145.

Table 5. Effect of peat application $(\mathrm{H}=4$, September 1995) and tillage on crop yield (at $15 \%$ grain moisture) and grain moisture at harvest in 1999-2000.

\begin{tabular}{|c|c|c|c|c|}
\hline \multirow{3}{*}{ Treatment } & \multicolumn{2}{|c|}{ Grain yield, $\mathrm{kg} \mathrm{ha}^{-1}$} & \multicolumn{2}{|c|}{ Grain moisture, $\%$} \\
\hline & Barley & Oats & Barley & Oats \\
\hline & 1999 & 2000 & 1999 & 2000 \\
\hline \multicolumn{5}{|c|}{ No peat applied } \\
\hline MP & 2000 & 5440 & 27.0 & 20.3 \\
\hline $\mathrm{SC}_{1}$ & 3350 & 5490 & 16.6 & 17.6 \\
\hline $\mathrm{SC}_{2}$ & 3180 & 5640 & 18.4 & 18.2 \\
\hline $\mathrm{DC}_{1}^{2}$ & 3120 & 5680 & 17.5 & 18.4 \\
\hline $\mathrm{DC}_{2}$ & 2770 & 5520 & 20.4 & 21.5 \\
\hline \multicolumn{5}{|l|}{ Peat applied } \\
\hline MP & 2430 & 5720 & 25.6 & 17.6 \\
\hline $\mathrm{SC}_{1}$ & 3460 & 5750 & 15.6 & 16.6 \\
\hline $\mathrm{SC}_{2}$ & 3340 & 5830 & 17.1 & 17.3 \\
\hline $\mathrm{DC}_{1}^{2}$ & 3240 & 5790 & 16.9 & 17.1 \\
\hline $\mathrm{DC}_{2}$ & 3100 & 5670 & 17.7 & 18.5 \\
\hline \multicolumn{5}{|l|}{ Peat means } \\
\hline $\mathrm{P}-$ & 2890 & 5560 & 20.0 & 19.2 \\
\hline $\mathrm{P}+$ & 3110 & 5750 & 18.6 & 17.4 \\
\hline $\mathrm{HSD}_{0.05}$ & $\mathrm{NS}^{1}$ & 180 & 1.4 & NS \\
\hline \multicolumn{5}{|c|}{ Tillage means } \\
\hline MP & 2220 & 5580 & 26.3 & 18.9 \\
\hline $\mathrm{SC}_{1}$ & 3410 & 5620 & 16.1 & 17.1 \\
\hline $\mathrm{SC}_{2}$ & 3260 & 5730 & 17.7 & 17.8 \\
\hline $\mathrm{DC}_{1}^{2}$ & 3180 & 5730 & 17.2 & 17.7 \\
\hline $\mathrm{DC}_{2}$ & 2940 & 5600 & 19.0 & 20.0 \\
\hline $\mathrm{HSD}_{0.05}$ & 280 & $\mathrm{NS}^{1}$ & 4.0 & 2.7 \\
\hline
\end{tabular}

$1 \quad \mathrm{NS}=$ not significant at $\mathrm{P}<0.05$

HSD $=$ Tukey's Honestly Significant Difference

$\mathrm{MP}=$ mouldboard ploughing to $20 \mathrm{~cm}, \mathrm{SC}_{1}=$ one shallow stubble cultivation to $8 \mathrm{~cm}, \mathrm{SC}_{2}=$ two shallow stubble cultivations to $8 \mathrm{~cm}, \mathrm{DC}_{1}=$ one deep stubble cultivation to $15 \mathrm{~cm}, \mathrm{DC}_{2}=$ two deep stubble cultivations to $15 \mathrm{~cm}$. P- = soil without peat application, $\mathrm{P}+=$ peat amended soil.

Stubble cultivation left more grains of the previous crop (oats) for better germination and establishment (in 1999) than did ploughing. This indicates that unwanted crops are better managed in general by ploughing than by stubble cultivation. However, Pekrun and Lutman (1998) found the highest persistence of oilseed rape when the seeds were ploughed immediately after harvest. They report that delaying cultivation reduced the persistence of seeds. In the present study, soils were tilled 3-4 weeks after harvest.

\section{Conclusions}

Based on two years of data and one large field experiment, neither tillage method nor peat application had a dramatic effect on weed quantity or species composition. However, ploughing does favour certain species, such as C. album, while stubble cultivation favours volunteer crops. Consequently, when choosing the tillage method for a particular field, one should consider the 
Vanhala, P. \& Pietola, L. Effect of tillage and peat on weed infestation

weed flora and intended use of the crop. When producing quality seed grain, for instance, ploughing seems to be a superior method for controlling volunteer crops. In other cases, infestations of C. album, L. purpureum or F. officinalis would be easier to reduce by adopting stubble cultivation. The mechanism of action of different tillage methods on weeds seems to be in part through effects on soil moisture; differences in weed populations induced by tillage methods were greater in dry years than in years with abundant precipitation. The risk of peat significantly increasing weed problems appears to be low.

Acknowledgements. We thank Risto Tanni (MTT) for technical support at the field site, and Eira-Maija Tanni and coworkers (MTT) for analyses of weed flora. The Association for Peat Cultivation and the Ministry of Agriculture and Forestry are gratefully acknowledged for financial support. We thank Carol Ann Pelli for linguistic revision of the paper.

\section{References}

Bayer 1992. Important crops of the world and their weeds. Scientific and common names, synonyms, and WSSA/WSSJ approved computer codes. Business group crop protection, Bayer AG, Leverkusen, Germany. Second edition. $1682 \mathrm{p}$.

Boström, U. 1999. Type and time of autumn tillage with and without herbicides at reduced rates in southern Sweden. 1. Yields and weed quantity. Soil and Tillage Research 50: 271-281.

Carson, K.H., Cralle, H.T. \& Chandler, J.M. 1999. Triticum aestivum and Lolium multiflorum interaction during drought. Weed Science 47: 440-445.

Chachalis, D. \& Reddy, K.N. 2000. Factors affecting Campsis radicans seed germination and seedling emergence. Weed Science 48: 212-216.

Clements, D.R., Benoit, D.L., Murphy, S.D. \& Swanton, C.J. 1996. Tillage effects on weed seed return and seedbank composition. Weed Science 44: 314-322.

Erviö, L.-R. 1972a. Growth of weeds in cereal populations. Journal of the Scientific Agricultural Society of Finland 44: 19-28.

Erviö, L.-R. 1972b. Lämpötilan ja poutajakson vaikutus jauhosavikan (Chenopodium album L.) ja viljan väliseen kilpailuun. Abstract: The effect of temperature and dry-weather period on the competition between Chenopodium album L. and some spring cereals. Journal of the Scientific Agricultural Society of Finland 44: 138-148.

Feldman, S.R., Alzugaray, C., Torres, P.S. \& Lewis, P. 1997. The effect of different tillage systems on the composition of the seedbank. Weed Research 37: 71-76.

Forcella, F., Wilson, R.G. \& Dekker, J. 1997. Weed seed bank emergence across the Corn Belt. Weed Science 45: 67-76.

Gill, K.S. \& Prihar, S. 1983. Cultivation and evaporativity effects on the drying patterns of sandy loam soil. Soil Science 135: 367-376.

Grundy, A.C., Mead, A. \& Bond, W. 1996. Modelling the effect of weed-seed distribution in the soil profile on seedling emergence. Weed Research 36: 375-384.
Gutterman, Y., Corbineau, F. \& Côme, D. 1992. Interrelated effects of temperature, light and oxygen on Amaranthus caudatus $\mathrm{L}$. seed germination. Weed $R e$ search 32: 111-117.

Hartmann, K.M. \& Nezadal, W. 1990. Photocontrol of weeds without herbicides. Naturwissenschaften 77: 158-163.

Lee, J.H., Lee, C.W. \& Chang, Y.H. 1994. Effects of environmental conditions on germination of Galium spurium L. Korean Journal of Weed Science 14: 228232. [Abstract 2597 in Weed Abstracts 44, 7: 353.]

Mohler, C.L. \& Galford, A.E. 1997. Weed seedling emergence and seed survival, separating the effects of seed position and soil modification by tillage. Weed Research 37: 147-155.

Mulugeta, D. \& Stoltenberg, D.E. 1997a. Increased weed emergence and seed bank depletion by soil disturbance in a no-tillage system. Weed Science 45: 234241.

Mulugeta, D. \& Stoltenberg, D.E. 1997b. Weed and seedbank management with integrated methods as influenced by tillage. Weed Science 45: 706-715.

Omami E.N., Haigh, A.M., Medd, R.W. \& Nicol, H.I. 1999. Changes in germinability, dormancy and viability of Amaranthus retroflexus as affected by depth and duration of burial. Weed Research 39: 345-354.

Patterson, D.T. 1995. Effects of environmental stress on weed/crop interactions. Weed Science 43: 483-490.

Pekrun, C. \& Lutman, P.J.W. 1998. The influence of postharvest cultivation on the persistence of volunteer oilseed rape. Aspects of Applied Biology 51: 113118.

Pietola, L. \& Tanni, R. 2003. Response of seedbed physical properties, soil $\mathrm{N}$ and cereal growth to peat application during transition to conservation tillage. Soil and Tillage Research 74: 65-79.

Pietola, L., Tanni, R. \& Uusitalo, P. 2002. Response of seedbed physical properties and soil nitrogen to peat application during transition to conservation tillage system of spring cereals. Proceedings of the International Peat Symposium, Estonia. p. 161-168. 
Vol. 12 (2003): 133-145.

Pitkänen, J. 1994. A long-term comparison of ploughing and shallow tillage on the yield of spring cereals in Finland. Proceedings of 13th ISTRO. Denmark. II 709-719.

Pollard, F. \& Cussans, G.W. 1981. The influence of tillage on the weed flora in a succession of winter cereal crops on a sandy loam soil. Weed Research 21: 185-190.

Ranta, E., Rita, H. \& Kouki, J. 1991. Biometria. Tilastotiedettä ekologeille. Yliopistopaino, Helsinki. 569 p. (in Finnish).

Salonen, J., Hyvönen, T. \& Jalli, H. 2001. Weeds in spring cereal fields in Finland - a third survey. Agricultural and Food Science in Finland 10: 347-364.

Skuterud, R., Semb, K., Saur, J. \& Mygland, S. 1996. Impact of reduced tillage on the weed flora in spring cereals. Norwegian Journal of Agricultural Sciences 10: 519-532.

Steel, R.G.D. \& Torrie, J.H. 1981. Principles and procedures of statistics $-A$ biometrical approach. $2^{\text {nd }}$ ed. McGraw-Hill International Book Company, Singapore.
Steiner, J.L. 1989. Tillage and surface residue effects on evaporation from soils. Soil Science Society of American Journal 53: 911-916.

Swanton, C.J., Shrestra, A., Roy, R.C., Ball-Coelho, B.R. \& Knezevic, S.Z. 1999. Effect of tillage systems, N, and cover crop on the composition of weed flora. Weed Science 47: 454-461.

Teasdale, J.R., Beste, C.E. \& Potts, W.E. 1991. Response of weeds to tillage and cover crop residue. Weed Science 39: 195-199.

Tørresen, K.S. 1998. Emergence and longevity of weed seeds in soil with different tillage treatments. Aspects of Applied Biology 51: 197-204.

Vanhala, P. \& Pitkänen, J. 1998. Long-term effects of primary tillage on above-ground weed flora and on the weed seedbank. Aspects of Applied Biology 51: 99-104.

Yli-Halla, M. \& Mokma, D.L. 2001. Soils in a young landscape on the coast of Southern Finland. Agricultural and Food Science in Finland 9: 291-302.

\title{
SELOSTUS
}

\section{Kynnöstä luopumisen ja turvelisäyksen vaikutus savimaan rikkakasvillisuuteen kevätviljakasvustossa}

\author{
Petri Vanhala ja Liisa Pietola \\ MTT (Maa- ja elintarviketalouden tutkimuskeskus) ja Helsingin yliopisto
}

Kenttäkokeessa Jokioisilla verrattiin useiden eri syyssänkimuokkausmenetelmien ja normaalin syyskynnön vaikutuksia savimaan rikkakasvillisuuteen. Tutkitut sänkimuokkausmenetelmät olivat kultivointi kertaalleen tai kahdesti joko 8 tai $15 \mathrm{~cm}$ :n syvyyteen. Kokeen perustamisen yhteydessä elokuussa 1995 tehdyn turvelisäyksen $\left(200 \mathrm{~m}^{3} \mathrm{ha}^{-1}\right)$ avulla pyrittiin nopeuttamaan kyntämättömän savimaan rakenteen parantumista ja kuivuuden kestävyyttä. Koekasveina olivat vuosina 1996, 1998 ja 2000 kaura sekä vuosina 1997 ja 1999 ohra. Rikkakasvien lukumäärä ja massa mitattiin hyvin kuivana vuonna 1999 sekä edellistä sateisempana vuonna 2000.

Kyntö suosi selkeästi jauhosavikan (Chenopodium album) esiintymistä etenkin kuivissa olosuhteissa. Kynnöstä luopuminen vähensi myös punapeipin (Lamium purpureum) ja peltoemäkin (Fumaria offi- cinalis) esiintymistä. Muuten eri sänkimuokkausmenetelmät tai turvelisäys eivät vaikuttaneet ratkaisevasti rikkakasvien runsauteen tai lajien määrään.

Edellisen kesän viljelykasvia kasvoi sänkimuokatuilla mutta ei mainittavasti kynnetyllä maalla. Näin ollen siemenviljelmillä kyntö puoltaa paikkaansa perusmuokkausmenetelmänä.

Eri kasvilajien runsastuminen eri lailla muokatuissa maissa näkyi selvimmin kuivana vuonna. Kun satoi riittävästi, rikkakasveja esiintyi tasaisemmin eri käsittelyissä. Turvelisäyksen vaikutus rikkakasvien esiintymiseen oli tässä tutkimuksessa vähäinen. Turvelisäys paransi viljelykasvien kasvua, minkä seurauksena rikkakasvien määrä ei päässyt lisääntymään. Turvelisäys ei siten aiheuttaisi ainakaan suuresti rikkakasvien runsastumista. 
